Spiritual Yarning : Craft-making as Getting Along in Everyday Life

\author{
Myllys, Riikka
}

2020-12

Myllys , R 2020 , ' Spiritual Yarning : Craft-making as Getting Along in Everyday Life ' , Journal of Religion in Europe , vol. 13 , no. 1-2 , pp. 121-143 . https://doi.org/10.1163/18748929-13010007

http://hdl.handle.net/10138/327460

https://doi.org/10.1163/18748929-13010007

unspecified

acceptedVersion

Downloaded from Helda, University of Helsinki institutional repository.

This is an electronic reprint of the original article.

This reprint may differ from the original in pagination and typographic detail.

Please cite the original version. 


\section{Spiritual Yarning: Craft-making as Getting Along in Everyday Life}

This article investigates how spirituality relates to craft-making. Spirituality is understood to have both religious and nonreligious content depending on the person. The data was collected in a one-year observation period and interviews. The results show that spirituality related to craft-making may be both religious and nonreligious. It is noteworthy, however, that religious and nonreligious spirituality are related to different aspects of craft-making: the social and prosocial aspects of craft-making are mostly religiously spiritual, whereas individually-centred aspects are not. Altogether, the spirituality of craft-making is largely immanent and wellbeing-oriented. As such, its focus is on getting along in everyday life.

Keywords: craft-making, everyday life, spirituality, wellbeing, women

\section{Introduction - craft-making as spirituality}

Textile craft-making as a hobby has become a global, yet rather Western, phenomenon, and even a boom at the beginning of the twenty-first century. ${ }^{1}$ A lot of themes related to the meaningfulness of life are linked to this boom. According to earlier studies, craft-making creates and strengthens social relations. ${ }^{2}$ It also gives people a way of participating in charity and doing

\footnotetext{
${ }^{1}$ e.g. Minahan, Stella \& Julie Wolfram Cox, "Stitch'nBitch: Cyberfeminism, a Third Place and the New Materiality," Journal of Material Culture 12/1 (2007), 5-21.

2 e.g. Faye Lynn King, "Social Dynamics of Quilting," World Leisure Journal 43/2 (2001), 26-29; Maura Kelly, "Knitting as a feminist project?," Women's Studies International Forum 44 (2014), 133-144; Anna Kouhia, Unraveling the Meanings of Textile Hobby Crafts (PhD, University of Helsinki, 2016); Anna Kouhia, "Categorizing the Meanings of Craft: A Multi-Perspectival Framework for Eight Interrelated Meaning Categories," Techne Series - Research in Sloyd Education and Craft Science A 19/1 (2012); Jane Maidment \& Selma Macfarlane, "Craft Groups: Sites of Friendship, Empowerment, Belonging and Learning for Older Women," Groupwork 19/1 (2009), 10-25; Kathleen W. Piercy \& Cheryl Cheek, "Tending and Befriending: The Intertwined Relationships of Quilters," Journal of Women \&
} 
good for others, which are perceived as a meaningful part of the hobby. ${ }^{3}$ Craft-making furthers wellbeing in several other ways: it provides makers with satisfaction, optimism, a way of organizing thoughts and experiences, opportunities for personal growth, and empowerment. It has therapeutic effects and fosters the feeling of self-managing, gives a sense of value and meaning in life, and enables coping with negative feelings. ${ }^{4}$ It also offers a means to express identity ${ }^{5}$ and creativity. ${ }^{6}$

Existential themes are an important part of craft-making. In speech, magazine stories, and other literature, the new Western craft-making activity is often related to the spiritual realm, especially meditation. ${ }^{7}$ Based on these sources, it seems that craft-making is indeed seen as practice of spirituality - and it is valued for this. However, in the academic literature there are only a few references to this phenomenon. In her study, Riley describes how craft-making is a spiritual

\footnotetext{
Aging 16/1-2 (2004), 17-33; Sinikka Pöllänen, "Crafts as Leisure-Based Coping: Craft Makers' Descriptions of their Stress-Reducing Activity," Occupational Therapy in Mental Health 31/2 (2015), 83-100; Sinikka Pöllänen, "Elements of Crafts that Enhance Well-being," Journal of Leisure Research 47/1 (2015), 58-78; Sinikka Pöllänen \& Laura Voutilainen, "Crafting Well-being: Meanings and Intentions of Stay-at-Home Mothers' Craft-Based Leisure Activity," Leisure Sciences 40/6 (2018), 617-633; Sherry Schofield-Tomschin \& Mary A. Littrell, "Textile Handcraft Guild Participation: A Conduit to Successful Aging," Clothing and Textiles Research Journal 19/2 (2001), 41-51.

3 e.g. Piercy \& Cheek, "Tending and Befriending."

${ }^{4}$ Pöllänen, "Crafts as Leisure-Based Coping"; Pöllänen, "Elements of Crafts that Enhance Well-being"; Sinikka Pöllänen, "The Meaning of Craft: Craft Makers' Descriptions of Craft as an Occupation," Scandinavian Journal of Occupational Therapy 20/3 (2013), 217-227; Sinikka Pöllänen, "Homing and Downshifting through Crafts," Reorientation of Teacher Education Towards Sustainability through Theory and Practice, ed. Ulla Härkönen, (University of Eastern Finland, 2013), 275-290; See also Ann Futterman Collier, "The Well-being of Women Who Create with Textiles: Implications for Art Therapy," Art Therapy 28/3 (2011), 104-112; Kouhia, "Categorizing the Meanings of Craft"; Frances Reynolds, "Managing Depression through Needlecraft Creative Activities: A Qualitative Study" The Arts in Psychotherapy 27/2 (2000), 107-114.

${ }^{5}$ e.g. Collier, "The Well-being of Women Who Create with Textiles"; Addie Martindale \& Ellen McKinney, "SelfSewn Identity: How Female Home Sewers use Garment Sewing to Control Self-Presentation," Journal of Consumer Culture (2018); Pöllänen \& Voutilainen, "Crafting Well-being"; Jill Riley, "Weaving an Enhanced Sense of Self and a Collective Sense of Self through Creative textile-making," Journal of Occupational Science 15/2 (2008), 63-73; Schofield-Tomschin \& Littrell, "Textile Handcraft Guild Participation"; Joyce Starr Johnson \& Laurel E. Wilson, “'It Says You really Care': Motivational Factors of Contemporary Female Handcrafters," Clothing and Textiles Research Journal 23/2 (2005), 115-30.

${ }^{6}$ Emily L. Burt \& Jacqueline Atkinson, "The Relationship between Quilting and Wellbeing," Journal of public health 34/1 (2011), 54-9; Collier, "The Well-being of Women Who Create with Textiles"; Kouhia, "Categorizing the Meanings of Craft"; Pöllänen, "Crafts as Leisure-Based Coping"; Schofield-Tomschin \& Littrell, "Textile Handcraft Guild Participation."

${ }^{7}$ e.g. Callie Janoff, "The Church of Craft: Making our Own Religion," Handmade Nation. The Rise of DIY Art, Craft and Design, eds. Faythe Levine and Cortney Heimerl (New York: Princeton Architectural Press, 2008), 54-57; Tara Jon Manning, Mindful Knitting: Inviting Contemplative Practice to the Craft (Boston: Tuttle Publishing, 2004); Janet Severi Bristow \& Victoria A. Cole-Galo, The Prayer Shawl Companion: 38 Knitted Designs to Embrace, Inspire, and Celebrate Life (Singapore: Taunton Press, 2008).
} 
exercise for a few of her interviewees; its repetitiveness acts as a prayer and meditation. ${ }^{8}$ This comes close to Fisk's argument of similar features related to the emphasis on subjective wellbeing in the current craft-making phenomenon and spirituality. She calls it craft-making's subjective turn. ${ }^{9}$ Fisk broadens her perspective to state that in general craft-making is both deeply spiritual and a spiritually empowering action. She sees it as one way of being "at home in the world," citing the emeritus Archbishop of Canterbury, Rowan Williams, who sees the desire "to be at home in the world" as "a very deeply religious impulse." ${ }^{10}$ Fisk does not directly indicate, how far craft-making is experienced or expressed as spiritual on an individual level. That is the aim of this study: to explore spirituality from the point of view of the ordinary craft makers.

Riley's and Fisk's studies point to the same direction: craft-making has "something more" in it, at least to some people. This is compatible with the usual talk and magazine writing about craftmaking. In the academic literature, however, this is both almost invisible and barely analysed. As Fisk has stated, the question of "something more" comes close to (late) modern themes of wellbeing and spirituality. Since craft-making is popular today, spirituality related to both wellbeing and craftmaking touches a large group of people. In the light of this, studying craft-making as spirituality offers fascinating perspectives on the wider religious realities in which people are living today.

Traditionally, indeed for centuries, craft-making has been, and remains, an important part of congregational involvement for women in Finland. Congregational craft-making groups continue to offer women an opportunity for social interaction, doing good for others, and participation in congregational life. ${ }^{11}$ This twofold approach to religion and spirituality that craft-making offers, that is, the late modern focus on subjective wellbeing and craft-making as a traditional practice of religion, gives interesting insight to today's religious landscape, its changes, and its plurality.

\footnotetext{
${ }^{8}$ Riley, "Weaving an Enhanced Sense of Self," 70.

${ }^{9}$ Anna Fisk, "So that you've got something for yourself': Knitting and implicit spirituality," Foundations and Futures in the Sociology of Religion, eds. Doggett, L. and Arat, A. (Abingdon \& New York: Routledge, 2017), 133-148.

${ }^{10}$ Anna Fisk, “To make, and make again': Feminism, Craft and Spirituality,” Feminist Theology 20/2 (2012), $161,173$.

${ }^{11}$ Anna-Liisa Voittosaari, Neulomayhtiöistä Ompeluseuroihin: Ompeluseurat Diakonian Ja Kristillisten Järjestöjen Työmuotona Suomessa 1800- Ja 1900-Luvuilla, (Jyväskylä: Jyväskylän yliopisto, etnologian laitos, 1994).
} 
However, the voice of craft makers has so far remained unheard in the academic literature on religion and spirituality. This research aims to fill this gap, at least from a Western perspective.

The core concept of this study is spirituality. In her research, Ammerman looks at the spiritual stories of everyday life. To her, spirituality is beyond us and the rational in everyday life. ${ }^{12}$ More important to Ammerman than the definition itself, however, is how and when people use the word and what kind of content it has. In her qualitative study, she interviewed US Americans on how their see spirituality in their everyday life and asked them to take pictures of spiritually meaningful situations. Based on her analyses, spirituality is given three different meanings: theistic spirituality, which is related to the existence of personal deities; extra-theistic spirituality, located in a person's inner world, relation with nature, and social relations with other people; and ethical spirituality, which connotes everyday compassion. None of these depends on the person's religiosity. However, theistic spirituality is more common among religious people whereas extra-theistic spirituality is usually expressed by non-affiliated individuals. Different spiritualities can be intertwined and expressed by the same person. In Ammerman's study, as well as its nonreligious forms, the term spirituality covers traditional religious expressions. ${ }^{13}$ This strengthens the case against the sharp division between religion and spirituality, stated for example by Steve Bruce. ${ }^{14}$

Ammerman's study has been criticized for being too Christian, Jewish, and middle class. ${ }^{15}$ As the author acknowledges, it is located in North America, a different religious landscape from

\footnotetext{
${ }^{12}$ Nancy T. Ammerman, Everyday Religion: Observing Modern Religious Lives (Oxford \& New York: Oxford University Press, 2007), 225; Nancy T. Ammerman, Sacred Stories, Spiritual Tribes: Finding Religion in Everyday Life (New York: Oxford University Press, 2014), 18-19.

${ }^{13}$ Nancy T. Ammerman, "Spiritual but Not Religious? Beyond Binary Choices in the Study of Religion," Journal for the Scientific Study of Religion 52/2 (2013), 258-78; Ammerman, Sacred Stories, Spiritual Tribes, 47-49; See also Brian Steensland, Xiaoyun Wang \& Lauren Chism Schmidt, "Spirituality: What Does it Mean and to Whom?," Journal for the Scientific Study of Religion 57/3 (2018), 450-472; Stefania Palmisano, "Spirituality and Catholicism: The Italian Experience," Journal of Contemporary Religion 25/2 (2010), 221-41; Anne Birgitta Pessi, "Privatized Religiosity Revisited: Building an Authenticity Model of individual-church Relations," Social Compass 60/1 (2013), 3-21; Kimmo Ketola et al., Socially Engaged Lutheranism: Finnish Attitudes to Faith and the Church in the Light of Surveys and Statistics, (Tampere: The Church Research Institute, 2016), 53.

${ }^{14}$ Steve Bruce, Secularization: In Defence of an Unfashionable Theory, (Oxford \& New York: Oxford University Press, 2011).

${ }^{15}$ Mary Ellen Konieczny, "Sacred Stories, Spiritual Tribes: Finding Religion in Everyday Life - A Book Review," Sociology of Religion 76/1 (2015).
} 
Europe ${ }^{16}$ Keeping these notions in mind, her thinking nevertheless offers a fruitful starting point and a lucid but nuanced tool to study craft-making and spirituality in the contemporary European and Nordic context. In this study, spirituality is understood in Ammerman's line as present in everyday life and its activities and capable of having both religious and nonreligious contents.

This article explores how spirituality relates to craft-making. In this article I focus on women. The reason for this is practical: due the highly gendered nature of textile craft-making ${ }^{17}$, my sample consisted of women only. As a gender-specific hobby craft-making has been closely related to womanhood both historically and today, and it is one of the ways to pass on practices of femininity. ${ }^{18}$ Gender affects how spirituality is practised and experienced in everyday life and religious communities. ${ }^{19}$ These are not, however, the focus of this article.

\section{Methods - spirituality in the data collection and analysis}

The data collection started with a year-long observation period. Observation makes it possible to see how and when religious and spiritual themes are presented and communicated in everyday life. ${ }^{20}$ From January to December 2016 I observed four different textile craft-making groups. Two were based in the Lutheran Church and two were not church-affiliated. Two did crafts for charity, and two did not. All the groups met in the Helsinki metropolitan area. The selection of the groups

\footnotetext{
${ }^{16}$ Ammerman, "Spiritual but Not Religious?," 272.

${ }^{17}$ Michael Bittman \& Judy Wajcman, "The Rush Hour: The Character of Leisure Time and Gender Equity," Social Forces 79/1 (2000), 165-89; Kelly, "Knitting as a feminist project?”; Joanne Turney, The Culture of Knitting, (New York: Berg, 2009), 5.

18 e.g. Sirpa Kokko, "Learning Practices of Femininity through Gendered Craft Education in Finland," Gender and Education 21/6 (2009), 721-34; Rozsika Parker, The Subversive Stitch: Embroidery and the Making of the Feminine, (London: I.B. Tauris, 2010); Marybeth C. Stalp, "Girls just Want to have Fun (Too): Complicating the Study of Femininity and Women's Leisure," Sociology Compass 9/4 (2015), 261-71.

${ }^{19}$ Meredith B. McGuire, Lived Religion: Faith and Practice in Everyday Life (Oxford: Oxford University Press, 2008), 159-161. See also Johanna Ahonen, "Finnish Women's Turn Toward India," Finnish Women Making Religion, eds. Terhi Utriainen and Päivi Salmesvuori (New York: Palgrave Macmillan, 2014), 217-235; Terhi Utriainen, "Lumottuja Naisruumiita Ja Jumalallisia Naisia. Uskontotiede Haastaan Luce Irigarayn,” Uskonnon Ja Sukupuolen Risteyksiä, eds. Johanna Ahonen and Elina Vuola. (Helsinki: Suomalaisen Kirjallisuuden Seura, 2015).

${ }^{20}$ Courtney Bender, Heaven's Kitchen: Living Religion at God's Love we Deliver, (Chicago: University of Chicago Press, 2003), 137.
} 
based on two different factors relating to spirituality and craft-making from different angles. The first is the fact that Finland has a long history of church-affiliated craft-making groups, through which women have participated and still participate in congregational life. ${ }^{21}$ The second is the current craft-making boom, which includes other social aspects unrelated to church, both globally and in Finland. ${ }^{22}$ Charity is an important motivator for craft-making in both phenomena. ${ }^{23}$ In this study, all the group members happened to be women.

The observation was participatory. ${ }^{24}$ In observing, I paid attention to the communication and conversations in the group. I also listened out for religious or spiritual themes and expressions in the discussions and how the group functioned. As one might have expected due to the types of group, groups differed in terms of the presence and place of religious themes in the meetings. The difference was not black and white: even though non-religiosity clearly was essential to the identity of one of the nonreligious groups, the other ended up organizing a worship service at which people could knit with a local Lutheran parish. Also, the church-affiliated groups differed in these terms: only one of them incorporated religious practices (such as devotion, praying and hymn singing) into every meeting. While the other group had no religious practices at all, discussions in it quite often touched deep religious or spiritual themes, such as participants' religious identity in the midst of the highly secularized neighbourhood.

When the observation period was finished, I started the interviews. During the observation I had had and followed several discussions. Based on these, I asked to interview women who had said or done something I wanted to look into in more depth. I was especially interested in the meanings, including spiritual ones, given to craft-making. One interviewee was Helena ${ }^{25}$ (aged 49), who spoke

\footnotetext{
${ }^{21}$ Voittosaari, Neulomayhtiöistä Ompeluseuroihin: Ompeluseurat Diakonian Ja Kristillisten Järjestöjen Työmuotona Suomessa 1800- Ja 1900-Luvuilla.

${ }^{22}$ Kelly, "Knitting as a feminist project?," 140-142; Minahan \& Wolfram Cox, "Stitch'nBitch," 6-7; Anna Rauhala, Neulonnan taito, (Helsinki: Suomen muinaismuistoyhdistys, 2019), 201-212; Hye Young Shin \& Ji Soo Ha, "Knitting practice in Korea: A geography of everyday experiences," Asian Culture and History, 3/1 (2011), 105-144.

${ }^{23}$ e.g. Piercy \& Cheek, "Tending and Befriending."

${ }^{24}$ Kim Knott, "Insider/outsider perspectives," The Routledge Companion to the Study of Religion, ed. John Russell Hinnells, (London: Routledge, 2010, 2nd ed.), 243-258.

${ }^{25}$ The women are given pseudonyms here based on the most popular Finnish female names in their birth decade.
} 
about a service she had attended where they had been able to do crafts. I also wanted to interview a variety of women in terms of age, education, and social relations (not only from the same group of friends). I interviewed four women from each group, sixteen interviews in total. The interviewed women were between 40 and 70 years of age, with equal numbers from each decade. They had both lower and higher educational backgrounds. The women represented quite a comprehensive picture of Finnish women's religiosity: some defined themselves as religious, the majority belonged to the Evangelical Lutheran Church but were not active, while some defined themselves as nonreligious and did not belong to the church either. None of them worked in the church and none had any theological education. All lived in the Helsinki metropolitan area. The interviews were semistructured and they were recorded and then transcribed. The interviews took from 15 minutes to one and half hours, averaging one hour.

Spirituality related to craft-making was one of the six themes in my interview frame and it was taken up by me. I usually asked: "How do you see that spirituality is part of your craft-making?" or "Can you see that there are some spiritual dimensions in your craft-making?" In the interviews I used two Finnish words for spirituality side by side. Hengellisyys and henkisyys can both be translated as spirituality in English, but they usually have a slightly different tone: hengellisyys can be seen as more traditional and institutionally-oriented spirituality whereas henkisyys usually refers to more individually-defined or nonreligious spirituality. ${ }^{26}$ The use of these two words in parallel allowed the interviewed women to choose the one they associate with craft-making. Women also reflected on the different connotations of the words in relation to craft-making. As Susanna (aged 38) pondered: "Well, I can't see craft-making as religiously spiritual [hengellisyys]. Maybe it can be nonreligious spirituality [henkisyys] on some level, like winding down or stress reduction, maybe [...] But I can’t really see that it would be related to religious spirituality [hengellisyys].” In this

\footnotetext{
${ }^{26}$ Eila Helander, "Spiritualiteetti Kirkkososiologian Näkökulmasta," Teologinen Aikakauskirja 110/3 (2005), 247-52; Kimmo Ketola, "Kaupunkien Uusi Henkisyys," Urbaani Usko. Nuoret Aikuiset, Usko Ja Kirkko, eds. Teija Mikkola, Kati Niemelä, and Juha Petterson. (Tampere: Kirkon tutkimuskeskus, 2006), 305-316.
} 
study I usually use the words religious spirituality or religion when the interviewed women talked about hengellisyys and nonreligious spirituality or spirituality to refer to henkisyys.

The research is data-driven: the data was examined using qualitative content analysis and the results of the analysis are discussed with the literature. The interview data of this study is based on the answers the women gave to the question about the relation of craft-making and spirituality and the definitions of spirituality and its relation to craft-making come from the women themselves. The data includes other quotes from elsewhere in the interviews where spirituality or religion were explicitly mentioned. That happened especially when the women from the church-affiliated groups talked about their group and motives for participating. References to explicit expressions of religion or spirituality in my observation notes are included in the data. Those could be found especially in the church-affiliated groups. The observation material focuses more on the place and nature of spirituality in the particular craft-making environment than the actual experienced relation of spirituality and craft-making. Overall, the interview data is much more nuanced than the observation notes on this topic, so it is weighted more heavily in the analysis.

\section{Findings}

This study explores the relation between craft-making and spirituality. The analysis shows that the spiritual dimensions of craft-making can be both religious and nonreligious and they relate to five aspects of craft-making: its contemplativeness, its capacity to be both therapeutic and empowering, its embodied nature, the opportunities it creates to do good for others, and social interaction.

\subsection{Contemplation}


The study participants highly valued the opportunity to settle down and be quiet by making crafts. For them, time making crafts was a relaxing (Tuula, aged 70) and peaceful moment (Maria, aged 40), which "calms one down" (Päivi, aged 53) and "brings rest” (Riitta, aged 65). All this indicates the contemplative aspect of craft-making. For these women, meditation, mindfulness, relaxation, winding or calming down, and gaining peace of mind, all of which craft-making offered, were closely related to spirituality, too.

When I asked about the relation of spirituality and craft-making Sari (aged 49), said: "I often find it to be quite meditative, because sometimes, especially if you do something difficult, you can't think of anything other than craft-making, and then it goes a little bit, like thinking about mindfulness or something like that, the presence here." Päivi was even more precise when she described the relation between craft-making and spirituality: "It (craft-making) is a meditating thing and a moment to calm down. So, if you use a religious terminology, it could be silence, when you can be in your thoughts and do that calming thing with your hands. That means a lot to me." However, not only the religious women saw the contemplative aspect of craft-making as spiritual; those who defined themselves as nonreligious did so, too. As Pirjo (aged 63) stated: "I cannot see craft-making as religious, because I am not a religious person and do not belong to the church. But spirituality - if one thinks that it is spirituality that you can have serenity and peace of mind and feel relaxed, then spirituality is also important.”

The contemplative capacity of crafts was undoubtedly the most commonly given answer when I asked about the relation of craft-making and spirituality in the interviews. The contemplativeness has some typical features in the data. Firstly, it seems to be very individualistic in nature: it generates good feelings and wellbeing especially for individuals. This is seen in Sari's, Päivi's, and Pirjo's stories above. In this sense it is quite the opposite of the meaningfulness of the social interaction related to craft-making, which the women also found important. The calming effect of craft-making, and the way of talking about it, seems to be purely individualistic in this study. In 
addition, God and religion seem almost entirely absent in these stories about the search for peace of mind by making crafts. Interestingly, this is also true for women who identified themselves as religious. For example, Maria found "certainly spiritual dimensions [in craft-making]. I myself might not think of craft-making as being very religiously spiritual.” It seems that seeking peace of mind through making crafts is more or less nonreligious but nonetheless spiritual, according the studied women.

As an individualistic and nonreligious spirituality, the contemplative aspects of craft-making reflect the religious landscape both in Finland and more broadly in Europe. ${ }^{27}$ It also has some common ground with Ammerman's extra-theistic spirituality, which is not anchored in theistic images but is located in the core of the self and appears when one steps outside the ordinary business of life. ${ }^{28}$ Craft-making offered the studied women a chance to step outside everyday life. However, spirituality does not come to the fore only when the business of everyday life stops. Craft-making serves as a means to stop and step beyond everyday life and duties. This is true for Maria to whom "it [craft-making] is like a spiritual, spiritual lifeline [a small laugh]. It is also that when it is very busy and you take up your craftwork, you get like a mental break from other work, or other thoughts." It is precisely this capacity of craft-making that the women describe as spiritual.

In the women's stories, the contemplative spirituality of craft-making happens here and now. While Ammerman describes the inner-self spirituality as "finding one's own 'spark of the divine"” or "having "faith in myself,", 29 in this study the turn to oneself could best be described as calming down or having peace of mind. The tone is quite different; the spirituality related to craft-making here is clearly more immanent in nature. When the women spoke about craft-making as meditation or contemplation, they quite clearly focused on good feelings right here and now. Therefore, Fisk's description of spirituality of craft-making as "being at home in the world" comes closer to their

\footnotetext{
${ }^{27}$ Paul Heelas \& Linda Woodhead, The Spiritual Revolution: Why Religion is Giving Way to Spirituality, (Malden, MA: Blackwell, 2005); Ketola et al. "Socially Engaged Lutheranism," 55.

${ }^{28}$ Ammerman, "Spiritual but Not Religious?," 268-269.

${ }^{29}$ Ammerman, Sacred Stories, Spiritual Tribes, 39.
} 
experience. ${ }^{30}$ One of the most important goals of these women's hobby seems to be to get along in everyday life and the surrounding, immanent reality rather than reaching beyond it: for them, this in itself is a spiritual task.

This immanent, wellbeing-focused spirituality is also closely related to the use of Finnish word henkisyys. Self-oriented, wellbeing-focused spiritual language does not exclude more religious ways of speaking about spirituality in other circumstances. In this study both religious and nonreligious women talked about spirituality in these terms. Therefore, in the context of craftmaking, individual and wellbeing-centred spirituality does not seem to be the opposite of more traditional forms of religion and spirituality, but goes inside and alongside them.

\subsection{Therapeutic and empowering elements}

The above analysis shows that craft-making has a great capacity to bring relaxation and peace of mind on a spiritual level. Not just contemplation, but also therapeutic and empowering elements play an important role in the meaningfulness of the hobby. For instance, for Hannele (aged 64), craft-making was an important part of her grieving process and helped her through the dark times of her life. In her interview, Hannele told me how

last Christmas my sister's husband died [...] so I thought I somehow had to deal with this sadness and so I went to Snurre [a yarn store in Helsinki] and bought a really lovely grey, just a lovely grey yarn and then I made a shawl from it. It would have been Alander's Finch, which I am doing now. Well, any model, so kind of like stitch by stich I mourned and thought. And it was kind of like to my sister's late husband and my sister was sitting with me and we talked about him, so it was like that. And then in his funeral I had the shawl on my shoulders and $[\ldots]$ then my sister's daughter-in-law came there in the coffee ceremony to praise that 'oh, you have a beautiful shawl.' I that yeah, but now it has done its job for me, and I want to

\footnotetext{
${ }^{30}$ Fisk, “"To make, and make again'," 173.
} 
give this to you. And I gave it to her and put [it on her shoulders] and she absolutely loved it. [...] It had done its job for me.

In Ammerman's study, spirituality is often present in stories of death of close ones, regardless of the storyteller's religiosity. ${ }^{31}$ This is reflected in Hannele's story. The nature of spirituality or its relation to the act of knitting the shawl was not, however, specified, even though Hannele identified as Christian. Nevertheless, it seems that craft-making was a meaningful part of Hannele's grieving process: through it she did her mourning and by giving the finished shawl away she symbolized letting go of sorrow. The character of her spiritual process did not come out very clearly in her interview, she did not describe her story as a spiritual experience. However, the fact that she told it in response to my question about the spiritual aspects of craft-making hints that the role of knitting in her grief process was also meaningful to her spiritually.

Anneli's experiences can also be seen to reflect the therapeutic elements of craft-making. Craftmaking brought her new friends and a whole new life after many hard years: "Well, yes it [craftmaking] has actually saved [me]! Yes, it has brought so much content to my life." Her new knitting friends quite accidentally took her to the places where her family and ancestors had lived through the centuries. This came out when I asked about the relation of craft-making and spirituality: "After all, now that it [craft-making] has taken me there to my own roots and my past, it is kind of like some divine dispensation, or I met this kind of person [a new friend]." Many times during our interview, she repeated the experience of the divine dispensation related to craft-making and the chain of events it led her to: it was a totally life-changing experience for her. It was also how she called her journey to her roots and her new crafting friends who made it possible. The words Anneli used when she described craft-making and the things it had brought to her life give the strong impression of something deeper or divine. To Ammerman: "Spirituality is about mysterious

\footnotetext{
${ }^{31}$ Ammerman, Sacred Stories, Spiritual Tribes, 286-287.
} 
encounters and happenings that come to those who are open to them." ${ }^{32}$ Anneli's story is about exactly this.

In most of the interviews, however, the emotions related to craft-making were only positive. Crafts were mainly made in order to feel good and to bring joy to oneself. It was pleasurable (Päivi), enjoyable (Pirjo) and was empowering, as it gave feelings of success (Leena, aged 70) and capability (Maria). All in all, it was a fun and invigorating hobby, which balanced work and other duties in life. This was not, however, usually seen as spiritual. The only exception to this was Leena who thought "it is already religious spirituality that I consider it [craft-making] as a gift. I feel like I have received such a gift, which gives me the opportunity to delight my children, close ones. [...] Yes I do, I see it as a gift. Both for myself and as an opportunity to share. That's how I feel it. Strongly." It seems that her expression "such a gift" refers to something purely enjoyable and delightful - and at the same time it has a strong religious meaning for her.

A bigger question at stake is when and why some therapeutic and empowering elements of craft-making are labelled as spiritual while others are not. Two remarks on this: firstly, different emotions about craft-making seem to link spirituality differently. In the data, spiritual dimensions are featured especially when crafts are made as therapy or are related to particularly meaningful life events. Spirituality is less related to positive and enjoyable motives for making crafts. Secondly, the religiosity of a person seems to play quite a big part in labelling an emotion related to craft-making as spiritual. In this study, only with the women with a warm attitude to religion do this. Ammerman reaches the same conclusion: the more religiously active people are, the more everyday activities are spoken of as spiritual. ${ }^{33}$ This applies here to the relation of craft-making and spirituality.

\subsection{The body}

\footnotetext{
${ }^{32}$ Ammerman, "Spiritual but Not Religious?," 266.

${ }^{33}$ Ammerman, Sacred Stories, Spiritual Tribes, 301-302.
} 
Besides the mind and cognitive or emotional experiences, the interviewed women very concretely related craft-making to the body. Both McGuire and Sointu and Woodhead argue that the body is closely related to women's spirituality. ${ }^{34}$ Is that the case here? The answer is not straightforward. When I asked about the spiritual dimensions of craft-making, none of the women related it to the embodied nature of the activity. Yet their stories do give some hints at the bodily aspects of spirituality.

When I asked about craft-making and spirituality, Pirjo, said "of course sometimes one thinks, I have a tendency to get stuck and strained [pointed at her shoulders], like I need a massage [...] it would be nice if one came up with some kind of craft-making that could relax at the same time." Anneli, in turn, spoke about the repetitiveness of craft-making when I asked about the relation of craft-making and spirituality: "it [craft-making] calms down like that, the mind. And, of course, it is like a mantra, like putting in the needle and pulling it out and counting to seven and starting it over, like this." Neither of the women literally link the bodily aspects of craft-making to spirituality but the theme came up in context when we talked about it. It seems that on some level, the bodily aspects of craft-making do link to spirituality in their minds. It was not, however, spoken of as such.

What kind of spirituality, then, is craft-making as an embodied activity? In McGuire's study of lived religion, the body and the repetitiveness of everyday activities are given especially religious meanings ${ }^{35}$ as in Riley's study of craft-making. ${ }^{36}$ This case is different: the bodily aspects of craftmaking, if they can be found in the first place, are clearly not religious in this data. None of the respondents linked craft-making as an embodied activity to either God or religion. Instead, my respondents seem to relate the spiritual aspects of the body in craft-making more to themselves and personal wellbeing. As such, this links to the contemplative aspects of craft-making, such as

\footnotetext{
${ }^{34}$ McGuire, Lived Religion, 161, 182; Eeva Sointu \& Linda Woodhead, "Spirituality, Gender, and Expressive Selfhood," Journal for the Scientific Study of Religion 47/2 (2008), 259-76.

${ }^{35}$ McGuire, Lived Religion, 105-106, 118.

${ }^{36}$ Riley, "Weaving an Enhanced Sense of Self."
} 
repetitiveness. In this study, the bodily aspects of spirituality can thus be related to Sointu and Woodhead's thinking of spirituality as one way to focus on women's bodies and bodily wellbeing. ${ }^{37}$

\subsection{Doing good for others}

Doing good for others by craft-making was important to the studied women and spiritually meaningful to some of them. This was clearest for Annikki (aged 71), who gave her perspective on the relations of spirituality and craft-making by saying: "Well, there is the fact that you do good for another, for others. At least it is now that, if you can think of it, that it is (religiously) spiritual. That doing good [...] Should we not also think about that?" This well illustrates Annikki's religiosity: to her, doing good for others was the most integral part of religion. This was a motivation for her to attend her congregation's craft-making group: they did good for others and made crafts for charity.

Leena was a member of the same group as Annikki, and for the same reason. Responding to my question about craft-making and spirituality, she said that "I see it [craft-making] as a gift, both for myself and as an opportunity to share. [...] But on the other hand, I also feel that it is, in cases like this - because I feel that I am neither a preacher nor a proclaimer, and no other - such a wonderful opportunity to smuggle in [God's] Word. That's what is feels to me." When I asked what she meant by that, she explained that doing good for both people close to her and strangers by making crafts was her proclamation to the world, an "act of love," as she described it.

In both Annikki's and Leena's stories, craft-making is strongly related to religious spirituality: through it one can realize the Christian ideal of loving one's neighbour. This remains central to Finnish church-affiliated craft-making culture, traditionally one way for women to practice their religion by doing good for others and taking part in congregational charity work. ${ }^{38}$ In Finland, ethical religiosity is rooted in the Lutheran concept of everyday vocation and common priesthood:

\footnotetext{
${ }^{37}$ Sointu \& Woodhead, "Spirituality, Gender, and Expressive Selfhood."

${ }^{38}$ Voittosaari, Neulomayhtiöistä Ompeluseuroihin.
} 
serving others in the midst of everyday life is seen as a significant part of religious commitment. ${ }^{39}$ This study shows that craft-making offers one way of fulfilling this commitment: it is a way to practice religion, especially its altruistic aspects.

The ethical aspect of spirituality can easily be found in both Annikki's and Leena's stories, linking to what Ammerman describes as ethical spirituality, which is characterized by an ethical and compassionate life. ${ }^{40}$ The combination of ethical thinking and religious spirituality was an identifying marker and cornerstone of the group of which both women were members. This was clearly expressed, when the founder of the group visited one of its meetings. In my observation notes on 22 March 2016 I described how: "She [the founder] clearly has a very strong spiritual vision of the work [of the group] and a solid and warm relationship with Mother Teresa's order and its sisters." The group did charity work for Mother Theresa's order. This is a good example of what Ammerman calls Golden Rule Christianity, where doing good for others in everyday life is the determining factor of a person's religiousness. ${ }^{41}$ As Annikki said: "Well, yes, it [spirituality] is very much about taking others into account and things like that."

It is worth noting that in this study ethical thinking and doing good for others were related to spirituality only in a religious way. Annikki and Leena were not the only women who found the opportunity to do good for others by making crafts meaningful, but they were the only ones who talked about it as spirituality. This does not mean that altruistic or prosocial values were not important to religiously non-affiliated or nonreligious participants in this study; however, these respondents did not describe such values as spirituality.

\subsection{The social dimensions of spirituality}

\footnotetext{
${ }^{39}$ Maarit Hytönen, Kutsumus Ja Elämäntehtävä, (Tampere: Kirkon tutkimuskeskus, 2018); Ketola et al. "Socially Engaged Lutheranism," 25-26, 37.

40 Ammerman, "Spiritual but Not Religious?," 272; Ammerman, Sacred Stories, Spiritual Tribes, 45

${ }^{41}$ Nancy T. Ammerman, "Golden Rule Christianity: Lived Religion in the American Maistream," Lived Religion in America: Toward a History of Practice, ed. David Hall. (Princeton: Princeton University Press, 1997), 196-216.
} 
Social interaction was a meaningful part of craft-making, as can be seen in both the interviews and the observation notes. Themes related to spirituality were quite naturally featured in the two religiously oriented groups observed. However, religion was present in different ways in their meetings, in terms of means, content, and how it related to craft-making. In the first religious group, spirituality was integral to meetings and spiritual practice had its own, permanent place there. Every session opened with a devotion which included Bible reading, praying, and hymn singing and ended with evening prayer. As I wrote in my observation notes on 23 February 2016: "There was a final hymn that the group members could choose. Then they went into a circle where the Lord's blessing was read aloud. After the Lord's blessing, the women said, 'Good night, let Jesus be with you, do not forget Mother Teresa's work!' This was clearly something that was repeated every time in the group." Thus, in this group spirituality has a ritualistic nature and is related to God. Doing good for others is in important part of their group identity. As I noted during the observation on 3 May 2016: "For this group, clearly doing good and the church are important." As such, it is good example of both Ammerman's theistic and ethical spiritualities. ${ }^{42}$ Craft-making essential to both these spiritualities: through it the women can do "acts of love" (Leena), which is the basis of their religiosity. It is worth noting that these groups largely consist of retired women. The question of age came up in the observation period, when the women were very glad to have me attending, as a younger woman. This raises the question as to the future of this traditional Finnish craft-making phenomenon, which should be addressed in future studies.

The other religiously oriented group had no devotions or other organized practices of spirituality, even though a local pastor took part in the meetings. Nevertheless, participants often discussed themes such as death or religious identity and usually on the initiative of some group member, not the pastor. As I wrote in my observation notes on 20 November 2016:

\footnotetext{
${ }^{42}$ Ammerman, "Spiritual but Not Religious,” 266, 272.
} 
The group talks about big things like death. It has come up in one way or another almost every time. So too this time when the death of someone was mentioned. There is also talk of funerals and relatives. It is somehow interesting how often the theme of death has been repeated in meetings. I ponder the group as a religious or spiritual community: there is no recurring religious rite or element, no initial devotion, end devotion, prayer, hymn, no such thing there. But what is very characteristic of the group is that they can talk about death and do it (often).

Besides death, participants quite often raised the question of their religious identity in the meetings. This was nourished by the fact that the women experienced their neighbourhood to be highly secularized. Sometimes these two, death and religious identity, intertwined:

Susanna wondered what an unbelieving worldview or an atheist worldview is. She also told us how a nonreligious acquaintance had responded she would flower in the wild when her child asked what would happen when she died. Susanna wondered what kind of answer that is and how to choose to believe [in God] as an adult if there were no building materials or language. (Observation notes, 18 September 2016.)

According to Ammerman, this kind of free conversation as a part of parish activity is very fruitful in terms of supporting the spiritual consciousness of the members. When everyday life events are shared among people who are open to talking about them on a spiritual level, spiritual understanding and expression of it becomes stronger. ${ }^{43}$ This group and its spirituality fulfilled this function: religion was not practised, but fundamental questions were discussed. The place of craftmaking in this was two-sided: "Crafts, on the other hand, are a bit of a side-line in that group. In that sense, it is maybe a bit like an old-time craft club that doing crafts allows you to sit down and commune and chat.” (Observation notes, 20 November 2016).

Making crafts itself is not spiritual in this group - but it creates the space for spirituality to be expressed. As Kristiina (aged 39) said: "I think that in my mind it [craft-making as spirituality] fits

\footnotetext{
${ }^{43}$ Ammerman, Sacred Stories, Spiritual Tribes, 301-302.
} 
that environment [the group], and the pastor, too." However, members of that group did not usually see the spirituality of craft-making as religious, but as contemplative, and mainly nonreligious. As Susanna said: "Well, I can’t see craft-making as religiously spiritual. Maybe it can be nonreligious spirituality on some level, like winding down or stress reduction, maybe [...] But I can't really see that it would be related to religious spirituality." Craft-making does not fit this group's idea of religious spirituality. This is clear difference from the other church-related group. Why? One answer may be the age difference: while the women in the charity-oriented group were in their 70s, the average age in the other group was 40 . This affects the religious realities they are living in. The members of the charity-oriented group, have lived in a somewhat homogenous Lutheran environment and they related their craft-making to a Lutheran understanding of everyday vocation, where serving others in everyday life is part of one's religious commitment. ${ }^{44}$ In the context in which the younger women live, their religious identity is constantly challenged from the outside. Such an environment also emphasizes the boundaries between what is religious and what is not. In this case, craft-making is labelled as belonging to individual and nonreligious spirituality. ${ }^{45}$

Perhaps the most interesting social group in terms of spirituality was the nonreligious group which decided to organize the knitting worship service with the local Lutheran congregation. This was congregation's regular, weekly communion service, but on this occasion, people could do crafts there. The idea for this event came from a group organizer who had attended such a worship service with her friend: "Helena had been to a knitting church and said: 'There we were knitting and had the Eucharist.' [...] Helena had also been in contact with the local parish to see if there could be a similar event there, but nothing had happened." (Observation notes, 7 September 2016.) Finally, they found the right person to contact and the service was held six months later. The spiritual content of this process is quite ambiguous. Even though the purpose of such a worship service was to link craft-making to the practice of religion and spirituality, it seems that the motivation to

\footnotetext{
${ }^{44}$ Ketola et al. "Socially Engaged Lutheranism," 22, 25-26, 37.

${ }^{45}$ E.g. Heelas \& Woodhead, The Spiritual Revolution.
} 
organize it did not explicitly include these aspects. When I interviewed the organizer, Helena, she described the knitting worship she had attended: "So when I was there, in that knitting church [it was led by] the same sort of active woman as I am, as we have, here. It wasn't anything more remarkable than that." When I asked about her religiousness, she replied: "I might not be such a spiritual being." The reality may have been more nuanced because during the observation I noticed that Helena was wearing a cross. Nevertheless, she described the worship as just a new and interesting social, craft-related activity and not, at least explicitly, a place to link spirituality to craft-making.

All in all, the spirituality related to social dimensions of craft-making in this study is more religious than nonreligious. This was true for Hannele, who did not participate in any of the churchaffiliated groups but "would love to be involved in a spiritual knitting community like the church's [...] After all, it doesn't need to be organized by the church, but in a spiritual knitting community where everyone is like confessing Christians." In contrast, none of the women longed for nonreligiously spiritual craft-making community. This might be for two reasons. First, church-related craft-making activity and the habit of doing good by making crafts together for religious purposes is well-known in Finland. ${ }^{46}$ So spirituality and the social aspects of craft-making may be quite automatically connected from a religious angle. Secondly, because contemplative aspects of craftmaking were individual, they may not have taken up in the craft groups or, at least, not talked about as spirituality.

\section{Conclusions}

In this study I have analysed how spirituality relates to craft-making. The data indicates that the spiritual dimensions of craft-making can be both religious and nonreligious and they relate to five

\footnotetext{
${ }^{46}$ Voittosaari, Neulomayhtiöistä ompeluseuroihin.
} 
aspects of craft-making: its contemplativeness, its capacity to be both therapeutic and empowering, its embodied nature, the opportunities it creates to do good for others, and social interaction. It is noteworthy that religious and nonreligious spirituality are related to different aspects of craftmaking: while religious spirituality can mainly be found in the social and altruistic forms, the nonreligious spirituality is related to more individualistic contents of craft-making, such as contemplativeness. The clear distinction between religious and nonreligious spirituality in craftmaking points in two directions: first, the relationship between spirituality and wellbeing in craftmaking and, secondly, the religious craft-making tradition in Finland.

Earlier research indicates that one important aspect of today's craft-making boom is its capacity to further personal wellbeing. ${ }^{47}$ This study shows that wellbeing and happiness are related to spirituality and the contemplativeness of craft-making gets strong spiritual nuances. In his research on religion in the Nordic countries, Bäckström argues that the self-centred quest for happiness and wellbeing is existential in nature and he calls it "second wave" or "free-floating" spirituality. ${ }^{48}$ His argument applies well to these findings: the quest for contemplativeness and feeling good have spiritual content in relation to craft-making. This type of spiritual content includes themes related to self-care and healing; in gendered studies of religion these are related to a spirituality that gives both permission and tools to focus on women's bodies and wellbeing. ${ }^{49}$ This study shows that craftmaking can act as a channel for such spiritualities, which focus mainly on the individual. As such, Fisk's analysis of spirituality related to the subjective turn of craft-making ${ }^{50}$ would seem to be a good description of these spiritual aspects of craft-making. This applies well to the current

\footnotetext{
47 e.g. Pöllänen, “Crafts as Leisure-Based Coping”; Pöllänen, "Elements of Crafts that Enhance Well-being”; Pöllänen, "The Meaning of Craft."

${ }^{48}$ Anders Bäckström, "Religion in the Nordic Countries: Between Private and Public," Journal of Contemporary Religion, 29/1 (2014), pp. 69.

49 e.g. Sointu \& Woodhead, "Spirituality, Gender, and Expressive Selfhood."

${ }^{50}$ Fisk, "'So that you've got something for yourself'."
} 
European religious landscape, where individually oriented spirituality has gained a strong foothold. ${ }^{51}$

The contemporary craft-making phenomenon explored in this study is accompanied by a more traditional, church-related Finnish craft-making heritage. Doing charity by making crafts and social interaction between women are key elements of this. ${ }^{52}$ For the studied women, this tradition is clearly related to religious spirituality, and doing good for others by making crafts becomes one form of religious practice. This is close to both the Lutheran concept of serving others in the midst of ordinary life as everyday vocation and Ammerman's theistic and ethical spiritualities, which emphasize both the relationship with deities and doing good for others. ${ }^{53}$ Religious spirituality is only related to craft-making in one of the two religious groups studied here. This charity-oriented group represents the traditional model of church-related craft-making activity. In the other churchrelated group, religious themes were discussed but they were not directly related to craft-making. In addition to the charity-oriented craft-making activity of the one church-related group, religious spirituality was also related to the empowering and therapeutic aspects of making crafts, but only by those participants who identified as religious.

Religious aspects of craft-making are thus limited to women who participate in traditional church-affiliated craft-making activity or identify as Christian. This relates to Ammerman's argument that religiously active people are more likely to see "a layer of spiritual reality alongside the mundane everyday world" as they have learnt the language to do so in their religious communities. ${ }^{54}$ Interestingly, personal religious identity is not that decisive in more individualistic and nonreligious aspects of spirituality: these were associated with craft-making by both religious and nonreligious women. All in all, the women's religious identification does not seem to be the only defining factor when they label craft-making as religiously or non-religiously spiritual.

\footnotetext{
${ }^{51}$ Heelas \& Woodhead, The Spiritual Revolution; Ketola et al. "Socially Engaged Lutheranism," 55.

52 Voittosaari, Neulomayhtiöistä ompeluseuroihin.

${ }^{53}$ Ketola et al. Socially Engaged Lutheranism, 25-26; Ammerman, "Spiritual but Not Religious," $266,272$.

${ }^{54}$ Ammerman, Sacred Stories, Spiritual Tribes, 301.
} 
Instead, each individual's view is influenced by more specific questions related to personal religious identity, the religious language used, the group they belong to and overall aim of their hobby. For craft-making women, nonreligious spirituality lives alongside - and sometimes inside the more traditional forms of religiosity. Altogether, the spirituality of craft-making is largely immanent and wellbeing-oriented. As such, it is focused on getting along in everyday life.

All in all, this study augments the picture of the contemporary Western craft-making phenomenon by underlining its spiritual dimensions, which have been more or less invisible in the previous studies of craft-making. Particularly, it emphasizes the importance of the contemplative element of craft-making. Considering how common both spiritual and nonspiritual contemplative aspects of craft-making are for the studied women, it is surprising that they have received so little previous attention. Contemplation is at the very core of the meaningfulness of their hobby.

\section{References}

Ahonen, Johanna, “Finnish Women’s Turn Toward India,” in: Terhi Utriainen \& Päivi Salmesvuori (eds.), Finnish Women Making Religion (New York: Palgrave Macmillan, 2014), 217-235.

Ammerman, Nancy T., "Golden Rule Christianity: Lived Religion in the American Mainstream," in: David Hall (ed.), Lived Religion in America: Toward a History of Practice (Princeton: Princeton University Press, 1997), 196-216.

Ammerman, Nancy T., "Studying Everyday Religion: Challenges for the Future," in: idem (ed.), Everyday Religion: Observing Modern Religious Lives (Oxford \& New York: Oxford University Press, 2007), 219-238.

Ammerman, Nancy T., "Spiritual but Not Religious? Beyond Binary Choices in the Study of Religion," Journal for the Scientific Study of Religion 52/2 (2013), 258-278. 
Ammerman, Nancy T., Sacred Stories, Spiritual Tribes: Finding Religion in Everyday Life (New York: Oxford University Press, 2014).

Bäckström, Anders, "Religion in the Nordic Countries: Between Private and Public," Journal of Contemporary Religion 29/1 (2014), 61-74.

Bender, Courtney, Heaven's Kitchen: Living Religion at God's Love We Deliver (Chicago: University of Chicago Press, 2003).

Bittman, Michael, \& Judy Wajcman, "The Rush Hour: The Character of Leisure Time and Gender Equity," Social Forces 79/1 (2000), 165-189.

Bristow, Janet Severi, \& Victoria A. Cole-Galo, The Prayer Shawl Companion: 38 Knitted Designs to Embrace, Inspire, and Celebrate Life (Singapore: Taunton Press, 2008).

Bruce, Steve, Secularization: In Defence of an Unfashionable Theory (Oxford \& New York: Oxford University Press, 2011).

Burt, Emily L., \& Jacqueline Atkinson, “The Relationship between Quilting and Wellbeing,” Journal of Public Health 34/1 (2011), 54-59.

Collier, Ann Futterman, "The Well-being of Women Who Create with Textiles: Implications for Art Therapy," Art Therapy 28/3 (2011), 104-112.

Fisk, Anna, “"To Make, and Make Again': Feminism, Craft and Spirituality,” Feminist Theology 20/2 (2012), 160-174.

Fisk, Anna, “'So That You've Got Something for Yourself”: Knitting and Implicit Spirituality,” in: Luke Doggett \& Alp Arat (eds.), Foundations and Futures in the Sociology of Religion (Abingdon \& New York: Routledge, 2017), 133-148.

Heelas, Paul, \& Linda Woodhead, The Spiritual Revolution: Why Religion is Giving Way to Spirituality (Malden: Blackwell, 2005).

Helander, Eila, "Spiritualiteetti kirkkososiologian näkökulmasta,” Teologinen Aikakauskirja 110/3 (2005), 247-252. 
Hytönen, Maarit, Kutsumus ja elämäntehtävä (Tampere: Kirkon tutkimuskeskus, 2018).

Janoff, Callie, "The Church of Craft: Making our Own Religion," in: Faythe Levine \& Cortney Heimerl (eds.), Handmade Nation: The Rise of DIY Art, Craft and Design (New York: Princeton Architectural Press, 2008), 54-57.

Johnson, Joyce Starr, \& Laurel E. Wilson, “'It Says You Really Care': Motivational Factors of Contemporary Female Handcrafters," Clothing and Textiles Research Journal 23/2 (2005), 115130.

Kelly, Maura, “Knitting as a Feminist Project?," Women's Studies International Forum 44 (2014), $133-144$.

Ketola, Kimmo, "Kaupunkien uusi henkisyys,” in: Teija Mikkola, Kati Niemelä, \& Juha Petterson (eds.), Urbaani usko: Nuoret aikuiset, usko ja kirkko (Tampere: Kirkon tutkimuskeskus, 2006), $305-316$.

Ketola, Kimmo, et al., Socially Engaged Lutheranism: Finnish Attitudes to Faith and the Church in the Light of Surveys and Statistics (Tampere: The Church Research Institute, 2016).

King, Faye Lynn, “Social Dynamics of Quilting,” World Leisure Journal 43/2 (2001), 26-29.

Knott, Kim, "Insider/Outsider Perspectives," in: John Russell Hinnells (ed.), The Routledge Companion to the Study of Religion, $2^{\text {nd }}$ ed. (London: Routledge, 2010), 243-258.

Kokko, Sirpa, "Learning Practices of Femininity Through Gendered Craft Education in Finland," Gender and Education 21/6 (2009), 721-734.

Konieczny, Mary Ellen, "Sacred Stories, Spiritual Tribes: Finding Religion in Everyday Life—A Book Review," Sociology of Religion 76/1 (2015), 121-122.

Kouhia, Anna, "Categorizing the Meanings of Craft: A Multi-perspectival Framework for Eight Interrelated Meaning Categories," Techne Series A 19/1 (2012), 25-40.

Kouhia, Anna, Unraveling the Meanings of Textile Hobby Crafts (Helsinki: University of Helsinki, 2016). 
Maidment, Jane, \& Selma Macfarlane, “Craft Groups: Sites of Friendship, Empowerment, Belonging and Learning for Older Women," Groupwork 19/1 (2009), 10-25.

Manning, Tara Jon, Mindful Knitting: Inviting Contemplative Practice to the Craft (Boston: Tuttle Publishing, 2004).

Martindale, Addie, \& Ellen McKinney, Self-sewn Identity: How Female Home Sewers Use Garment Sewing to Control Self-Presentation.

https://journals.sagepub.com/doi/10.1177/1469540518764238 (accessed 7 July 2020). (2018).

McGuire, Meredith B., Lived Religion: Faith and Practice in Everyday Life (Oxford: Oxford University Press, 2008).

Minahan, Stella, \& Julie Wolfram Cox, "Stitch'nBitch: Cyberfeminism, a Third Place and the New Materiality," Journal of Material Culture 12/1 (2007), 5-21.

Palmisano, Stefania, "Spirituality and Catholicism: The Italian Experience," Journal of Contemporary Religion 25/2 (2010), 221-241.

Parker, Rozsika, The Subversive Stitch: Embroidery and the Making of the Feminine (London: I.B. Tauris, 2010).

Pessi, Anne Birgitta, "Privatized Religiosity Revisited: Building an Authenticity Model of Individual-church Relations," Social Compass 60/1 (2013), 3-21.

Piercy, Kathleen W., \& Cheryl Cheek, “Tending and Befriending: The Intertwined Relationships of Quilters," Journal of Women \& Aging 16/1-2 (2004), 17-33.

Pöllänen, Sinikka, "Homing and Downshifting through Crafts," in: Ulla Härkönen (ed.), Reorientation of Teacher Education Towards Sustainability through Theory and Practice (Joensuu: University of Eastern Finland, 2013), 275-290.

Pöllänen, Sinikka, “The Meaning of Craft: Craft Makers' Descriptions of Craft as an Occupation,” Scandinavian Journal of Occupational Therapy 20/3 (2013), 217-227. 
Pöllänen, Sinikka, “Crafts as Leisure-based Coping: Craft Makers' Descriptions of Their Stressreducing Activity," Occupational Therapy in Mental Health 31/2 (2015), 83-100.

Pöllänen, Sinikka, "Elements of Crafts that Enhance Well-being," Journal of Leisure Research 47/1 (2015), 58-78.

Pöllänen, Sinikka, \& Laura Voutilainen, "Crafting Well-being: Meanings and Intentions of Stay-athome Mothers' Craft-based Leisure Activity,” Leisure Sciences 40/6 (2018), 617-633.

Rauhala, Anna, Neulonnan taito (Helsinki: Suomen muinaismuistoyhdistys, 2019).

Reynolds, Frances, “Managing Depression Through Needlecraft Creative Activities: A Qualitative Study," The Arts in Psychotherapy 27/2 (2000), 107-114.

Riley, Jill, "Weaving an Enhanced Sense of Self and a Collective Sense of Self through Creative Textile-making," Journal of Occupational Science 15/2 (2008), 63-73.

Schofield-Tomschin, Sherry, \& Mary A. Littrell, "Textile Handcraft Guild Participation: A Conduit to Successful Aging," Clothing and Textiles Research Journal 19/2 (2001), 41-51.

Shin, Hye Young, \& Ji Soo Ha, "Knitting Practice in Korea: A Geography of Everyday Experiences," Asian Culture and History 3/1 (2011), 105-144.

Sointu, Eeva, \& Linda Woodhead, "Spirituality, Gender, and Expressive Selfhood," Journal for the Scientific Study of Religion 47/2 (2008), 259-276.

Stalp, Marybeth C., "Girls Just Want to Have Fun (Too): Complicating the Study of Femininity and Women's Leisure,” Sociology Compass 9/4 (2015), 261-271.

Steensland, Brian, Xiaoyun Wang, \& Lauren Chism Schmidt, "Spirituality: What Does It Mean and to Whom?," Journal for the Scientific Study of Religion 57/3 (2018), 450-472.

Turney, Joanne, The Culture of Knitting (New York: Berg, 2009).

Utriainen, Terhi, "Lumottuja naisruumiita ja jumalallisia naisia: Uskontotiede haastaa Luce Irigarayn,” in: Johanna Ahonen \& Elina Vuola (eds.), Uskonnon ja sukupuolen risteyksiä (Helsinki: Suomalaisen Kirjallisuuden Seura, 2015), 55-81. 
Voittosaari, Anna-Liisa, Neulomayhtiöistä ompeluseuroihin: Ompeluseurat diakonian ja kristillisten järjestöjen työmuotona Suomessa 1800- ja 1900-luvuilla (Jyväskylä: Jyväskylän yliopisto, etnologian laitos, 1994). 